\title{
WISATA ALAM DI KERESIDENAN PRIANGAN PADA PERIODE AKHIR KOLONIAL (1830-1942)
}

\author{
NATURAL TOURISM IN PREANGER REGENCY
}

AT THE LATE OF COLONIAL PERIOD (1830-1942)

\author{
Gregorius Andika Ariwibowo
}

Balai Pelestarian Nilai Budaya Bandung

JL. Cinambo No.136 Ujungberung-Bandung 42094

e-mail: andikaariwibowo@gmail.com

\begin{abstract}
Abstrak
Bumi Priangan telah sejak lama dikenal dengan pesona alam yang dimilikinya. Pesona alam Priangan sejak masa kolonial Belanda telah menarik para pelancong untuk mengunjungi wilayah ini. Kajian ini membahas faktor-faktor yang membuat alam Priangan mampu menarik kunjungan para turis pada periode akhir kolonial. Kajian ini menggunakan konsep terbentuknya suatu wilayah hingga mampu menjadi suatu destinasi wisata berdasarkan kajian Stephan Wearing, serta melihat pengaruh pemahaman orientalisme abad ke-19 dan ke-20 yang melatarbelakangi kunjungan para wisatawan terutama ke wilayah-wilayah jajahan. Berdasarkan arah kajian ini maka faktor-faktor yang menjadi dasar mengapa Priangan mampu menarik kunjungan para pelancong antara lain, 1) pesona dan keindahan alamnya; 2) sarana dan fasilitas pendukung wisata; 3) harmonis dan nyamannya kehidupan sosial dan budaya masyarakatnya; serta 4) pesona keindahan dataran tinggi dan gunung berapi di sekitar Priangan. Melalui kajian ini diharapkan mampu membuka ruang diskusi lain terkait perkembangan pariwisata di Hindia Belanda, dan Priangan pada khususnya.
\end{abstract}

Kata kunci: wisata alam, Priangan, sejarah, kolonial.

\begin{abstract}
Priangan has been known for its natural charm. The natural charm of Priangan, since the Dutch colonial period, has attracted travelers to visit this region. This study discusses the factors that generate Priangan nature attractive for the tourists at the end of the colonial period.It uses the concept of a region formation in becoming a tourist destination by Stephan Wearing studies, as well as the influence of Orientalism understanding of the $19^{\text {th }}$ and $20^{\text {th }}$ century behind the touristsvisits, especially to the colonies. Under the direction of this study, the factors which form the basis on why Priangan is capable of attracting the travelersare: 1) the charm and natural beauty; 2) the aids and tourist support facilities; 3) the harmony and the comfort of social and cultural life; and 4) the beauty of the highlands and volcanoes around Priangan. Through this study, it is expected to open up the space of discussions related to the development of tourism in the East Indies, especially in Priangan.
\end{abstract}

Keywords: Nature Tourism, Priangan, History, Colonial.

\section{A. PENDAHULUAN}

Semenjak masa kolonial Belanda, Priangan telah menjadi destinasi utama para turis yang datang baik dari Hindia Belanda maupun dari luar negeri.
Keindahan panorama alam, serta kehidupan suburban yang jauh dari keramaian kota-kota besar pada masa itu seperti Batavia, Semarang, dan Surabaya menjadi daya tarik utama para turis yang 
hendak mengunjungi Priangan. ${ }^{1}$ Para turis pada masa itu tidak saja mengunjungi Bandung namun juga kota-kota lain di sekitar Keresidenan Priangan pada masa itu seperti Cianjur, Sukabumi, Bandung, Garut, dan Tasikmalaya. Wilayah-wilayah ini memang menjadi destinasi utama para turis yang datang berkunjung ke Jawa dan Hindia Belanda.

Kajian ini membahas mengenai turisme dari sisi berkembangnya tempat yang menjadi destinasi wisata. Suatu wilayah tidak serta merta muncul begitu saja menjadi destinasi wisata. Ada hal-hal yang tentunya menjadi daya tarik bagi suatu wilayah untuk berkembang menjadi daerah tujuan wisata, terutama wisata alam. Kajian ini akan mencoba melihat bagaimana Keresidenan Priangan - sebagai sebuah ruang atau tempat (place) - mampu menjadi daya tarik bagi para pelancong untuk mengunjungi wilayah ini, serta faktor-faktor apakah yang menjadi pendorong dari berkembangnya pariwisata dan turisme di Keresidenan Priangan pada periode akhir kolonial?

Keresidenan Priangan sejak pertengahan abad ke-19 memang telah dikenal sebagai salah satu tujuan wisata di Hindia Belanda. Hal ini dengan ditunjang oleh keindahan panorama alam yang

\footnotetext{
1 Menurut Graeme Davison daerah suburban diartikan sebagai suatu wilayah pemukiman yang dibangun dan diperuntukkan untuk golongan borjuis dan kelas menengah perkotaan yang terpisah dari pusat wilayah ekonomi, bisnis, dan industri. Di daerah suburban ini terdapat berbagai bentuk sarana hiburan dan rekreasi. Di dalam wilayah suburban pun tata ruang kota diatur sedemikian rupa sehingga dapat terjaga kebersihan dan keamanan kota. Bandung dapat disebut sebagai kawasan suburban sejak tahun 1906 yakni semenjak ditetapkannya Kotapraja (Gemeente) Bandung sebagai calon Ibukota Hindia Belanda. Mulai saat itu pemerintah kolonial membangun berbagai sarana di kota ini yang ditujukan bagi masyarakat Eropa dan kelas menengah kolonial pada masa itu. (Stevenson, 2003: 18; Kunto, 2014: 14)
}

terdapat di wilayah ini. Kemudian pada abad ke-20, Kota Bandung — sebagai ibu kota Keresidenan Priangan-kemudian juga telah dikenal sebagai tempat wisata urban dengan menghadirkan berbagai tempat hiburan perkotaan Eropa seperti, restoran, hotel, taman, teater dan bioskop (Kunto, 2014).

Periode akhir kolonial yang berlangsung pada tahun 1830 hingga 1942 dipandang sebagai puncak kolonialisme Belanda di Nusantara. Kemajuan yang terjadi pada periode ini telah membuka Hindia Belanda kepada dunia luar. Arus mobilisasi yang terjadi di wilayah ini dengan disertai oleh berbagai kepentingan para pengunjungnya telah menciptakan dinamika kehidupan di Hindia Belanda, termasuk di dalamnya mengenai hal-hal yang terkait dengan pariwisata dan turisme.

\section{B. METODE PENELITIAN}

Kajian "Sejarah Perkembangan Pariwisata dan Turisme di Keresidenan Priangan pada Periode Akhir Kolonial" ini menggunakanpendekatan metode sejarah (penentuan tema, pengumpulan sumber, kritik sumber, dan historiografi) dengan lebih menekankan terhadap kajian historiografi dari sudut pandang sejarah sehari-hari (daily life history). Fernand Braudel menyatakan bahwa melalui kajian sejarah sehari-hari sejarawan akan dapat menemukan hal-hal kecil dari suatu rutinitas dan aktivitas manusia yang meskipun sederhana namun mampu memberikan pengaruh yang besar bagi jalannya suatu peristiwa sejarah. Selain itu melalui kajian sejarah sehari-hari dapat ditemui mengenai sisi yang unik dan menarik dari suatu rutinitas manusia dan masyarakat yang salah satunya adalah mengenai pariwisata. (Braudel, 1981, vol. I: 28-30).

Pariwisata sendiri terkait dengan kajian sejarah sehari-hari. Hal ini karena dalam kajian mengenai pariwisata terkait dengan gaya hidup, waktu luang (leisure time), hiburan, perjalanan, serta interaksi 
sosial dan budaya antarmanusia dan alam di sekitarnya (Wearing, et.al., 2010: 1).

Dalam mengupas mengenai dinamika pariwisata di Keresidenan Priangan pada periode akhir kolonial ini akan digunakan sumber-sumber yang berasal dari jurnal perjalanan (travelogue), media cetak, serta beberapa buku yang terkait dengan tema ini. Kajian ini akan menggunakan jurnal-jurnal perjalanan dari para pelancong yang mengunjungi Priangan. Beberapa jurnal yang digunakan antara lain ditulis oleh Elizah R. Scidmore (1897), Augusta de Wit (1905), A.J. Barnouw (tt), dan James Rush (2013) Selain itu akan digunakan juga buku-buku panduan mengenai pariwisata di Jawa yang dikeluarkan oleh Michel's Java Motoring Co. (tt) dan Official Tourist Bureau (1910, 1913) yang berisi tentang fasilitas-fasilitas wisata beserta tempat-tempat menarik yang dapat dikunjungi dan ditawarkan kepada para pelancong.

Kajian mengenai turisme di Hindia Belanda sendiri bukan merupakan hal yang baru dalam kajian historiografi di Indonesia. Achmad Sunjayadi (2007) membahas mengenai peran Lembaga Turisme Batavia (Vereeniging Toeristen Verkeer Batavia) dalam usaha pengembangan pariwisata pada masa Hindia Belanda. Sunjayadi mengulas mengenai peran lembaga ini dalam pembuatan berbagai media promosi dan usaha yang mereka lakukan dalam mendorong pariwisata dan mengundang turis yang datang mengunjungi Hindia Belanda.

Dalam artikelnya yang lain, Sunjayadi (2008) juga secara apik mengulas mengenai peran media, terutama melalui fotografi dalam mempromosikan dan mengenalkan pariwisata di Indonesia pada masa kolonial. Kajian Sunjayadi secara menarik mampu membuka perspektif baru dalam kajian mengenai turisme di Hindia Belanda secara umum. Namun secara lokalitas kewilayahan memang masih diperlukan kajian yang lebih mendalam untuk melihat perkembangan pariwisata dan pengaruhnya secara lokalitas, salah satunya yang terjadi di Keresidenan Priangan.

Michel Picard (2006) secara apik mengangkat sejarah pariwisata di Bali dari masa kolonial hingga ke masa Orde Baru. Ia mengupas bagaimana Bali "dibentuk" menjadi sebuah daerah destinasi wisata tanpa harus mengabaikan lokalitas budaya dan tradisi dari masyarakat Bali. Perkembangan pariwisata di Priangan pun telah disinggung pula oleh Hayoto Kunto (1989) mengenai pengaruh Hotel Savoy Homann bagi perkembangan pariwisata di Bandung. Kunto (2014) juga mengungkapkan beberapa kesan dari para turis, serta tempat-tempat yang menjadi destinasi para turis yang berkunjung ke Bandung.

Tempat wisata atau destinasi wisata tidak muncul begitu saja. Kajian ini ingin melihat mengenai bagaimana suatu tempat wisata dibentuk dan dikelola sehingga mampu menjadi daya tarik bagi para turis atau pengunjung yang datang ke suatu wilayah. Hal yang paling pertama dan utama dalam kajian turisme adalah mengenai tempat wisata. ${ }^{2}$

Suatu tempat atau wilayah dapat menjadi tempat wisata menurut John Urry (2002) ditentukan oleh keinginan dari para turis yang mencari suatu tempat untuk bersenang-senang yang menarik untuk memuaskan pandangan dan hasrat mereka akan sesuatu yang menyenangkan (consume visually). Para turis ini akan

${ }^{2}$ Chris Barker dengan berangkat dari analisis Michel Foucault mengartikan tempat (place) sebagai situs atau lokasi dalam ruang yang dibentuk dan dibuat menjadi bermakna oleh relasi-relasi sosial yang melibatkan kekuasaan dan ditandai oleh berbagai model identifikasi dan keterlibatan emosional. Oleh karena itu tempat bisa dipahami sebagai manifestasi terbatas dari produksi makna dalam ruang. Barker juga mengartikan tempat sebagai fokus pengalaman manusia, memori, hasrat, dan identitas, yang menjadi target dari identifikasi atau keterlibatan emosional (Barker, 2014: 205-206) 
memilih tempat untuk mereka kunjungi sebagai suatu bentuk representasi interaksi sosial dan budaya, identitas, dan gaya hidup yang dipahami oleh mereka.

Sementara menurut Wearing dan Wearing (Wearing and Wearing, 2001 dalam Wearing, et.al., 2010: 79) keinginan untuk melakukan perjalanan oleh para turis atau pelancong dipengaruhi oleh nilai, kepercayaan, hasrat, dan pengetahuan yang dimiliki oleh mereka untuk mencari kesenangan, hiburan, pengalaman, dan pengetahuan yang selama ini berada di luar dunia keseharian dan rutinitas mereka. Maka suatu tempat atau wilayah yang tadinya tidak atau hanya memiliki makna tertentu bagi penduduk lokal kemudian mampu berubah dan memiliki makna ekonomi dalam bentuk tempat wisata (Sites of Consumption) (Urry, 2002 dalam Wearing, et.al., 2010: 79). Wearing kemudian membagi tempat wisata ke dalam dua landscape(bentang) yakni alam (nature) dan kota (cityscape) (Wearing, 2010: 75). Dalam kajian mengenai perkembangan pariwisata di Keresidenan Priangan ini akan melihat pesona alam di Keresidenan Priangan, mampu menciptakan daya tarik yang menarik kunjungan para wisatawan dan pelancong yang mengunjungi wilayah ini pada periode akhir kolonial.

\section{HASIL DAN PEMBAHASAN}

1. Daya Tarik Pesona Tropika Hindia Belanda

Dalam kehidupannya manusia selalu terhubung dengan alam di sekitarnya. Dua pertiga kunjungan para turis dan pelancong selalu menjadikan alam sebagai tujuan utama mereka. Berbagai bentuk rekreasi alam seperti penjelajahan, berburu, menyelam, atau hanya sekadar rekreasi menikmati keindahan alam merupakan aktivitas yang paling dicari oleh para turis ketika menghabiskan liburan mereka (Wearing, et.al., 2010: 81). ${ }^{3}$

3 Menurut Levi-Strauss pesona alam selalu menjadi penghubung antara manusia dengan masa lalunya sebelum mereka hidup teratur dalam peradaban seperti saat ini. Sementara Iso
Pada abad ke-19 Dunia Tropis yang terbentang di khatulistiwa menjadi fantasi yang terbayangkan terutama oleh orangorang di belahan bumi utara seperti Amerika dan Eropa. Pesona dan eksotisme alam tropis seakan menyihir para petualang, evolusionis, ilmuwan, orientalis dan masyarakat awam dari Amerika dan Eropa untuk datang mengeksploitasi dan menjelajahi wilayah ini. David Weir menyebut hal ini sebagai Terra Fantastica (Weir, 2011: 2)

Dunia tropis seakan menghadirkan sihir dan magnet yang menarik bagi orangorang kulit putih untuk datang ke wilayah ini. Kekayaan dan keanekaragaman flora dan fauna; pesona budaya timur yang eksotis dan menawan; dunia alam liar yang penuh dengan misteri; kehidupan manusia yang masih sederhana dan tradisional menjadi imajinasi yang menumbuhkan rasa penasaran dari para orang kulit putih untuk datang dan berkunjung. ${ }^{4}$ Hal ini pun ditambah oleh berbagai foto ${ }^{5}$, buku, dan

Ahola menyatakan bahwa alam merupakan bagian dari diri manusia. Memisahkan alam dengan manusia berarti memisahkan manusia dari dirinya sendiri. Bagi Prohansky manusia terhubung dan berinteraksi dengan alam sampai kapan pun. (Levi-Strauss, 1964; Ahola, 1980; Prohansky, 1983 dalam Wearing, et.al., 2010: 80-81)

4 Pandangan ini memang merupakan pandangan yang berkembang di Eropa ketika itu. Hal inilah yang kemudian disampaikan oleh Edward Said sebagai Orientalisme. Kehidupan masyarakat dan alam tropis seakan dbentuk oleh masyarakat kulit putih sebagai bentuk superioritas mereka (dalam bidang pengetahuan, kebudayaan, dan kekuatan kolonial) atas dunia yang dipandang rendah, asing, dan eksotis oleh mereka yang dalam hal ini adalah dunia tropis. Menurut Said melalui "penemuan" dunia timur dan tropis orangorang kulit putih seakan memiliki hak untuk mengeksploitasi dan menginvasi Dunia Timur (Orient) baik alam, budaya, pengetahuan, bahkan manusianya. (Edward Said, 1968; Weir, 2011: 2-3)

5 Kajian lebih lengkap mengenai pengaruh fotografi kolonial terhadap perkembangan 
cerita perjalanan dari orang-orang yang pernah mengunjungi daerah-daerah tropis.

Di Eropa, dunia tropis Nusantara pertama kali muncul melalui cerita-cerita perjalanan dan buku-buku yang berisi tentang situasi dan kondisi kehidupan alam, budaya, dan masyarakatnya. Tulisan mengenai Hindia Belanda, terutama Jawa pertama kali disusun oleh Raffles melalui bukunya yang berjudul "History of Java". Buku ini berisi tentang banyak hal mengenai Pulau Jawa, mulai dari flora dan fauna, kekayaan alam yang dimiliki, kehidupan sosial dan budaya masyarakatnya, sistem pemerintahan dan ekonomi, serta peninggalan sejarah yang ada di pulau ini (Raffles, 1830). Selain Raffles buku karya Alfred Russel Wallace juga menjadi faktor penarik orang-orang Eropa dan Amerika untuk mengunjungi Hindia Belanda, serta Jawa pada masa kemudian. Buku-buku karya Wallace terutama Malay Archipelago menjadi salah satu buku pertama yang memuat mengenai Hindia Belanda secara apik. ${ }^{6}$ Ia membahas mengenai keanekaragaman flora dan fauna serta kehidupan sosial, politik, dan budaya masyarakat kolonial dan bumiputera di Hindia Belanda (Lays, 2001: 67). Meskipun Malay Archipelago tidak menggambarkan panorama kehidupan alam di Hindia Belanda secara utuh, namun buku ini mendorong para naturalis lain untuk datang mengunjungi Hindia, entah sebagai peneliti, orientalis, atau

pariwisata pada masa Hindia Belanda dapat dilihat pada artikel "Mengabadikan Estetika: Fotografi dalam Pariwista Kolonial di Hindia Belanda" oleh Achmad Sunjayadi (2008).

6 Alfred Russel Wallace adalah seorang naturalist berkebangsaan Inggris. Ia mengunjungi Kepulauan Indonesia dan Malaysia pada sekitar tahun 1854. Faktor pendorong ia mengunjungi wilayah ini adalah adanya keinginan dia untuk mempelajari mengenai evolusi manusia dan meneliti mengenai orang utan. Lebih jauh mengenai kiprah Alfred Russel Wallace selama di Malaya dan Hindia Belanda dapat dibaca dalam Stepan Nancy Leys (2001: 57-85). hanya sebagai pelancong yang penasaran dengan kehidupan alam tropis di Hindia yang mereka anggap penuh dengan petualangan dan tantangan. ${ }^{7}$

Salah satu faktor penting yang mendukung kunjungan para pelancong ke Hindia Belanda adalah keberadaan Pameran Kolonial Internasional yang digelar pertama kali di Amsterdam, Belanda pada tahun 1883. Pameran ini pada awalnya bermaksud untuk memperkenalkan produk industri dari tanah jajahan Belanda di Hindia Timur dan Hindia Barat kepada publik di Eropa. Namun, pada perkembangannya pertunjukan dan penampilan budaya dari Hindia Belanda justru menjadi daya tarik utama dari pameran ini. Pada pagelaran pertama "Pameran Kolonial Internasional" ini Pemerintah Kerajaan Belanda menampilkan kesenian, rumah dan kampung adat, serta kerajinan tangan yang berasal dari Aceh, Sunda, Ambon, Jawa, dan beberapa daerah lain di Nusantara (Bloembergen, 2006: 1-2). ${ }^{8}$

Pada "Pameran Kolonial Internasional" pertama ini ditampilkan keseluruhan bentuk kampung, serta keseharian dari para penduduknya yang tinggal sehari-hari di Hindia Belanda. Kemunculan kampung Sunda, Jawa, Ambon, dan Aceh beserta penduduknya menjadi sangat menarik di tengah

\footnotetext{
7 Wallace secara berlebihan menggambarkan konflik antara Orang Dayak dengan orang utan, serta menggunakan mitos-mitos lokal dalam beberapa kajiannya, sehingga seperti menggambarkan kehidupan alam tropis yang liar dan tidak beradab. Di sisi yang lain Wallace juga menggambarkan warna-warni alam, flora, dan fauna di Hindia Belanda yang begitu unik dan menarik, terutama mengenai beragam jenis burung yang terdapat di Indonesia Timur (Lays, 2001: 69-73).

${ }^{8}$ Pameran ini dirancang oleh orientalis Belanda ketika itu yakni P.J. Veth. Dibantu oleh anaknya Daniel Veth, P.J. Veth bermaksud menghadirkan budaya dan etnografi Hindia Belanda ke dalam pameran tersebut Nusantara (Bloembergen, 2006: 2).
} 
superioritas, hegemoni, dan dominasi kulit putih pada periode abad ke-19, terutama dalam hal kebudayaan, pengetahuan, dan kekuasaan. Bloembergen mengatakan bahwa ini merupakan suatu ajang pamer dunia "primitif" dan "eksotis" dari peradaban "lain" di belahan dunia timur kepada masyarakat "modern" Eropa. Namun, menurut Bloembergen hal ini juga mendorong ketertarikan orang-orang Eropa dan kulit putih untuk mempelajari dan mengetahui, bahkan kemudian mengunjungi kehidupan penduduk bumiputera di Hindia Belanda yang eksotis, seperti yang disampaikan pula oleh Daniel Veth ketika membawa "kampung" beserta penduduknya ke Belanda pada sekitar tahun 1882 (Bloembergen, 2006: 67). ${ }^{9}$

Menurut Christiane DemeulenaereDouyère pameran kolonial ini membawa dampak bagi perkembangan turisme di kawasan daerah-daerah jajahan. Hal ini terjadi karena pameran kolonial ini mempertemukan antara dua kebudayaan dan peradaban yang meskipun dibatasi oleh diskriminasi dan rasisme yang terjadi pada masa itu, namun menghadirkan ketertarikan dari para pengunjung untuk datang dan melihat langsung alam, budaya, perkampungan, dan masyarakat yang hidup di negeri-negeri daerah jajahan yang eksotis (Demeulenaere-Douyère, 2012: 83, 96). ${ }^{10}$

\footnotetext{
${ }^{9}$ Salah satu bentuk yang hampir serupa dengan pemandangan Kampung Hindia Belanda ketika itu mungkin saat ini seperti dengan paviliun rumah-rumah adat yang terdapat di Taman Mini Indonesia Indah, Jakarta.
}

${ }^{10}$ Pameran kolonial ini digelar secara teratur di negara-negara kolonial sejak tahun 1833. Jumlah pengunjung yang selalu meningkat pada setiap gelarannya ditunjang oleh semakin menariknya paviliun-paviliun dari daerahdaerah jajahan yang mewakili negara-negara kolonial ini. Seperti Belanda pada pameran 1883 membawa tema karakteristik budaya dan masyarakat Hindia; Pada tahun 1889 di Paris membawa kehidupan perkampungan Jawa; Pada tahun 1893 di Chicago menampilkan

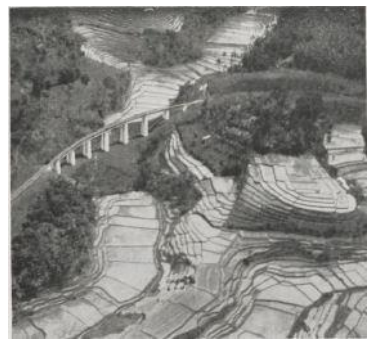

Gambar 1. Pemandangan alam Priangan dan rel kereta yang melintasinya Sumber: (KNILM, tt: 2)

Melalui rangkaian foto, berita perjalanan, buku-buku, dan pameran kolonial ini dunia timur yang tadinya merupakan terra incognita (Dunia yang tidak diketahui) menjadi terra fantastica (Dunia yang ajaib/luar biasa). Dunia timur kini menawarkan sesuatu yang penuh dengan rasa penasaran untuk ditelusuri, dijelajahi, dan dikunjungi. Kunjungan ke dunia timur pun semakin mudah pada paruh kedua abad ke-19 dengan dibukanya Terusan Suez dan terbukanya pelayaran kapal uap langsung dari Eropa ke Asia.

\section{Berwisata ke Bumi Parahyangan}

M.A.W. Brouwer seorang Belanda yang sempat tinggal di Bandung mengatakan bahwa "Bumi Pasundan diciptakan ketika Tuhan sedang tersenyum". Pendapat Brouwer ini bukan merupakan hal yang berlebihan pesona alam Bandung dan Bumi Parahyangan (Priangan) memang begitu indah dan mempesona. Deretan pegunungan yang mengelilingi Kota Bandung dengan berbagai keindahan panorama alamnya juga turut menawarkan kesejukan udara, kolam air panas alami, air terjun, dan

kehidupan perkampungan di Perkebunan Sinagar, Jawa Barat; Pada tahun 1900 di Paris membawa miniatur Candi Sari, Jawa Tengah; dan pada tahun 1931 membawa arsitektur dan miniatur pura di Bali. Pergelaran yang mengelilingi dunia para kolonialis inilah yang menjadi salah faktor penarik utama kunjungan wisatawan ke kawasan Hindia Belanda (Bloembergen, 2006: 7). 
suasana dataran tinggi yang elok. Hal ini pun masih ditambah dengan perkebunan teh, kopi, dan kina yang membentang di sepanjang deret dataran tinggi Priangan.

Keresidenan Priangan merupakan salah satu wilayah dimana orang-orang Eropa merasa nyaman untuk tinggal di wilayah ini. Suasana sejuk, nyaman, indah, dan damai begitu mempesona orang-orang Eropa yang mengunjungi wilayah ini. Europa in de Troupen merupakan julukan yang diberikan oleh orang-orang Eropa yang mengunjungi wilayah ini karena keindahan alam tropika Priangan yang terselubungi oleh kesejukan udara khas Eropa. Parijs van Java, Geneve van Java, Montpeiller of Java, dan Switzerland van Java merupakan julukan untuk kota-kota di wilayah Keresidenan Priangan untuk disandingkan dengan kesejukan, keindahan, kedamaian dan keasrian kotakota di Eropa.

Priangan berkembang seiring dengan dibukanya perkebunan kopi pertama oleh Peter Engelhard pada tahun 1789. Pada periode selanjutnya para Preangerplanters (pemilik perkebunan Priangan) mengembangkan wilayah ini menjadi pusat perkebunan terutama untuk komoditi kopi, teh, dan kina. ${ }^{11}$ Pada tahun 1808-1810 Gubernur Jenderal H.W. Daendles memerintahkan pembangunan Jalan Raya Pos yang melintasi pedalaman Jawa Barat. Pembangunan yang pada awalnya untuk sarana transportasi dan komunikasi militer ini kemudian dimanfaatkan untuk pengembangan perkebunan dan ekonomi di kawasan ini (Kunto, 2014: 11-13).

Pada tahun 1884 dibuka jalur kereta api yang menghubungkan antara Batavia hingga Bandung. dibukanya jalur kereta api ini semakin mempermudah perjalanan menuju Keresidenan Priangan.

11 Beberapa pemilik perkebunan besar di Keresidenan Priangan antara lain Pieter Engelhard, Andries de Wilde, Franz Wilhelm Junghuhn, K.A.R. Boscha (Kunto, 2014: 3344).
Pembangunan jalur kereta api yang mulanya digunakan untuk mempermudah transportasi hasil perkebunan, kemudian juga digunakan sebagai daya tarik wisata ke Keresidenan Priangan (Reitsma, 1930: 28).

Reitsma mencatat bahwa pembangunan jalur kereta api ini telah menjadikan Bandung dari sebuah desa dengan beberapa Orang Eropa yang berdiam di wilayah ini hingga menjadi kota terbesar ketiga di Hindia Belanda pada tahun 1930 (Reitsma, 1930: 28-29). Disamping itu kereta api kemudian menjadi primadona baru dari atraksi perjalanan wisata ke wilayah Priangan. Hal ini karena perjalanan menggunakan kereta api menuju Badung, Garut, atau Tasik menghadirkan pengalaman yang mengasyikkan. Para wisatawan akan melintasi deretan pegunungan, lembah, serta ditambah dengan pengalaman menegangkan ketika melintasi jalur-jalur kereta yang curam dan jembatan penghubung yang tinggi dan panjang. Dari Batavia para penumpang yang akan menuju Priangan akan berangkat dari Stasiun Koningsplein (Gambir). Biaya perjalanan kereta api untuk gerbong kelas pertama berkisar antara $f 0,45$ sampai $f$ 0,55 per kilometer, untuk gerbong kelas dua berkisar antara $f 0,3$ sampai $f \quad 0,4$ per kilometer, dan terakhir untuk gerbong kelas tiga berkisar $f 0,15$ untuk $250 \mathrm{~km}$ pertama, serta $f \quad 0,5$ untuk $250 \mathrm{~km}$ berikutnya. (Scidmore, 1897: 50-51; Official Tourist Bureau, tt: 13; Reitsma, 1930: 31).

Salah seorang pelancong pertama yang mengunjungi Keresidenan Priangan adalah Charles Walter Kinloch. Ia mengunjungi wilayah ini pada sekitar tahun 1852 dan begitu terkesan dengan perjalanannya melewati Jalan Raya Pos pada masa itu. Ia mengatakan perjalanan dengan kereta kuda dari Batavia hingga Buitenzorg (Bogor) ditempuh dengan sangat cepat dan setiap 5 -7 mil (8-11 km) didirikan pos-pos kuda untuk beristirahat dan disediakan penginapan kecil. 
Selanjutnya ketika memasuki dataran tinggi Priangan, ia harus menggunakan kerbau, kuda, dan gethek karena jalan yang sulit dan mendaki, serta harus melewati Sungai Citarum. Namun, selama perjalanan ia begitu mengagumi keindahan alam di wilayah ini. Kehidupan pedesaan yang asri, udara yang sejuk dan bersih, suasana kehidupan pedesaan yang menyenangkan, serta terutama pemandangan alam yang begitu indah dan mempesona dengan aneka bunga dan burung yang ia temui di sepanjang perjalanan (Kinloch, 1853 dalam Rush, 2013,:62-66).

Kinloch juga menetap sementara di sebuah desa yang bernama Bandong. Kinloch menyebut desa kecil ini sebagai Montpellier of Java karena cuacanya yang hangat dan udaranya yang sejuk. Daerah yang dikelilingi oleh perbukitan ini dalam gambaran Kinloch persis seperti Kota Montpellier di Prancis bagian selatan. Di Bandung, Kinloch tinggal di sebuah penginapan yang disediakan oleh seorang pemilik perkebunan kopi yang ia sebut sebagai Tuan L. Kinloch mengagumi kehidupan di perkebunan kopi ini. Melihat keindahan perkebunan kopi, tumbuhtumbuhan yang tumbuh di sekitar perkebunan, dan harum mewangi dari bijibiji kopi, kehidupan pekerja perkebunan, serta kebahagiaan dari Tuan L selaku pemilik perkebunan yang meninggalkan posisinya sebagai residen untuk mengelola perkebunan di wilayah ini (Kinloch, 1853 dalam Rush, 2013,:68-69).

Selain Kinloch, Elizah Scidmore juga pernah menghabiskan waktu selama di Priangan dengan tinggal di sebuah rumah perkebunan. Scidmore tinggal di sebuah perkebunan teh di Sinagar, Sukabumi di tempat inilah ia kemudian mengatakan bahwa Jawa merupakan "The Garden of the East". Di Sinagar, Scidmore mengatakan bahwa wilayah ini merupakan taman tropis yang sangat indah. Berbagai jenis tanaman dan bunga dapat tumbuh, udara yang segar dan sejuk, pemandangan lembah yang indah di antara dua gunung yakni Gunung Salak dan Gunung Gede, serta perkebunan kopi, teh, dan kina yang menghampar luas sepanjang mata memandang merupakan taman tropis yang begitu indah. Scidmore juga begitu terkesan dengan hujan tropis yang deras disertai gelegar halilintar, namun membawa kesejukan dan nyanyian hewan sesudahnya, serta yang menurut ia paling penting adalah memberikan kesuburan bagi tanaman kopi, teh dan kina, serta kehidupan di wilayah ini. Suasana yang menurutnya hanya ditemui di wilayah tropis khatulistiwa (Scidmore, 1897: 126127).

Rumah-rumah milik para tuan tanah ini selain digunakan oleh mereka pribadi juga sebagian digunakan sebagai penginapan para tamu dan pelancong yang berkunjung. Seperti yang disampaikan oleh Scidmore bahwa di rumah tersebut banyak terdapat berbagai jenis burung, seperti burung dara, kakatua, cendrawasih, dan aneka jenis burung bersuara indah, serta terdapat sebuah taman bunga yang ditanami dengan bunga mawar, melati, lili, anggrek, dan lainnya. Siulan burung dan aneka jenis dan warna bunga ini dalam benak Scidmore merupakan suatu pemandangan yang indah dan mengagumkan. Namun di antara berbagai jenis hewan dan bunga yang ada di rumah tersebut, hal yang paling menyenangkan bagi Scidmore adalah ketika ia disajikan berbagai jenis buah yang manis dan beraneka warna hal yang jarang ia temui di Amerika Serikat (Scidmore, 1897: 129130)

Tuan pemilik perkebunan pun sangat royal dengan mengadakan jamuan makan malam, pesta, dan pertunjukan seni yang bukan saja berasal dari Hindia, namun juga didatangkan langsung dari Eropa ataupun Amerika. Rumah-rumah perkebunan ini kemungkinan merupakan cikal bakal dari vila-vila yang tumbuh seiring dengan meningkatnya kunjungan para turis pada periode awal abad ke-20 (Scidmore, 1897: 129). 
Elizah Scidmore sendiri mengatakan kunjungannya ke Jawa memang telah ia rencanakan jauh-jauh hari. Hal ini bukan saja karena posisinya sebagai salah satu wartawan pertama majalah "National Geographic", namun karena rasa penasarannya akan Jawa seperti yang ia temui dalam Pameran Kolonial Internasional di Chicago pada tahun 1893. Ia begitu tertarik dengan presentasi pemerintah kolonial Belanda tentang perkebunan Sinagar serta penduduk bumiputera yang menampilkan berbagai jenis tarian dan musik selama acara berlangsung (Scidmore, 1897: 144).

Selama di rumah tersebut tuan pemilik perkebunan juga mengajak para tamu untuk ikut dalam kegiatan berburu, selain Scidmore, J.W.B. Money juga memiliki pengalaman dalam berburu di Priangan pada masa kolonial. Scidmore dan Money mengatakan bahwa para tamu yang akan berburu akan menunggang kuda menuju ke sebuah hutan tropis, para tamu ini dibantu oleh para penduduk bumiputera dan anjing mereka. Hewan-hewan yang diburu antara lain, harimau jawa, badak jawa, rusa, dan banteng jawa. Money mengatakan bahwa perburuan ini sangat ramai dan menyenangkan. Para pemburu Eropa ini menelusuri pedalamanpedalaman hutan yang masih lebat, pengalaman yang mengesankan terlebih bila mereka berhasil menembak rusa atau hewan-hewan langka seperti harimau dan badak (Scidmore, 1897: 133-134; Money, 1868 dalam Rush, 2013: 86-87).

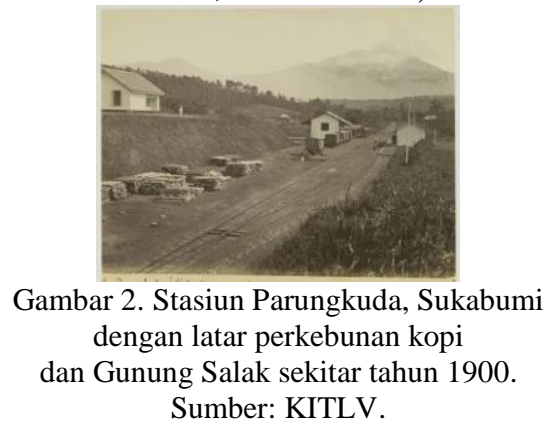

Kehidupan desa juga menarik perhatian para pelancong yang berkunjung ke Priangan. Ketika berkunjung ke sebuah desa di Priangan, Augusta de Wit sangat terkesan dengan suasana yang ada di desa ini. Ia menceritakan mengenai jalan menuju desa yang ia lalui hanyalah jalan tanah yang dikelilingi oleh berbagai tanaman buah-buahan dan bambu. Ia juga melihat sawah yang terhampar luas dan berpapasan dengan seorang anak yang menggembalakan kerbaunya. De Wit juga menceritakan mengenai keriangan seorang kakek yang sedang mengasuh anaknya, gambaran kehidupan alami para petani di Hindia yang penuh kebahagiaan, meskipun mereka dikekang oleh kolonialisme dan kesewenang-wenangan pemimpin kolonial dan tradisional mereka. De Wit terkesan pada kehidupan tradisional masyarakat petani ini, seperti mengenai selamatan sebelum proses menanam padi dan persembahan yang diletakkan di dekat pohon beringin memberi arti keharmonisan budaya masyarakat timur dengan alam dan lingkungan di sekitarnya. Kehidupan keluarga di desa dimana adanya rasa saling menghormati antarkeluarga begitu mengesankan De Wit, seperti ketika ia menceritakan kepatuhan anak kepada orang tuanya dan bagaimana sebuah keluarga besar hidup rukun dalam suatu areal lingkungan yang sama (De Wit, 1905: 268-282).

Selama di Sinagar Elizah Scidmore juga mengunjungi sebuah desa yang berada di bawah perkebunan. Suasana desa ini dikelilingi oleh pohon asam, bambu, dan buah-buahan, serta pohon beringin yang ada di batas desa. ${ }^{12}$ Berbeda dengan

12 Model dan arsitektur desa di Sinagar, Sukabumi ini sebenarnya pernah ia saksikan dalan Colonial Expo pada tahun 1893 di Chicago, Amerika Serikat. Hal ini karena pada saat itu yang menjadi sponsor pemerintah kolonial untuk pameran tersebut adalah pemilik perkebunan teh Sinagar, sehingga para pemilik ini membawa arsitektur desa dan sebagian penduduk sebagai "perlengkapan" pameran tersebut. Penduduk Sinagar ini juga dihadirkan dalam Colonial Expo yang juga diadakan pada tahun 1899 di Paris, Prancis (Scidmore, 1897: 143-144). 
De Wit yang memperhatikan struktur sosial dan kekerabatan di desa, Scidmore menceritakan mengenai pertunjukan kesenian yang ditampilkan oleh penduduk desa. Ia terkesan dengan penampilan wayang, tari, gamelan, dan berbagai alat musik dari bambu yang menghadirkan suara-suara yang indah dan unik yang ia lukiskan sebagai salah satu melodi yang paling mempesona di dunia timur (fascinating melody in the east) (Scidmore, 1897: 142-143).

Dunia tropis timur telah menarik para pelancong dari Eropa dan Amerika ini untuk singgah dan tinggal sejenak. Suasana kehidupan dunia timur yang eksotis seakan mampu menarik masyarakat barat saat itu untuk mengeksplorasi, menjelajahi, bahkan mempelajari alam dan budaya timur lebih dalam lagi. Di tengah pandangan etnosentrisme yang berkembang pada masyarakat kulit putih pada masa itu. Kehadiran mereka di tengah-tengah lingkungan budaya timur telah mengubah cara pandang mereka akan kekhasan dan kekayaan budaya timur yang penuh dengan nilai-nilai keindahan, kebijaksanaan, dan keharmonisan meskipun berada ditengahtengah cengkeraman kolonialisme dan imperialisme pada masa itu.

Masyarakat Sunda di Priangan menjadi salah satu wakil dari budaya timur pada masa itu yang mampu menghadirkan fantastica budaya timurbagi dunia barat, sehingga mengundang kunjungan para pelancong asing untuk singgah dan mengagumi budaya timur, khususnya Sunda pada masa itu. Hal ini bisa dilihat salah satunya dalam artikel berbahasa Inggris mengenai kehidupan masyarakat Pasundan dalam majalah semi wisata $M o o i$ Bandoeng yang berjudul "The Land of Laughter and Sunshine". Artikel ini berisi mengenai kehidupan masyarakat Pasundan yang ditujukan bagi para pelancong berbahasa Inggris (Mooi Bandoeng, Maret 1939: 19-20; Mooi Bandoeng, April 1939: 49-50).

\section{Pesona Dataran Tinggi Bumi Parahyangan}

Pada awal abad ke-20 hingga akhir kekuasaan kolonial Belanda pada tahun 1942, para pelancong ini memiliki tujuan atraksi alam yang tidak kalah menarik yakni kawah gunung berapi dan air terjun. Mereka juga memanfaatkan alat transportasi baru pada masa itu yakni mobil dan sepeda motor untuk menjelajahi dan mengunjungi panorama alam, khususnya di Tanah Priangan.

Dalam panduan perjalanan yang dikeluarkan oleh Official Tourist Bureau Batavia terdapat beberapa gunung, gunung berapi, air terjun, dan dataran tinggi yang dapat dijelajahi di sekitar Keresidenan Priangan. Dalam ulasannya mengenai Keresidenan Priangan Official Tourist Bureau menyampaikan bahwa Keresidenan Priangan adalah salah satu daerah yang memiliki pemandangan yang sangat indah di Jawa. Di wilayah ini terdapat banyak gunung berapi yang berada saling berdekatan. Atraksi alam yang dapat dinikmati di sekitar gununggunung ini, antara lain kolam air panas, pemandangan kawah aktif, danau uap dan sulfatara, air terjun, serta pemandangan yang begitu mengagumkan. Selain itu para turis juga dapat menikmati udara yang sejuk dan menyehatkan di resort-resort yang berada di sekitar objek wisata (Tourist, 1913: 25).

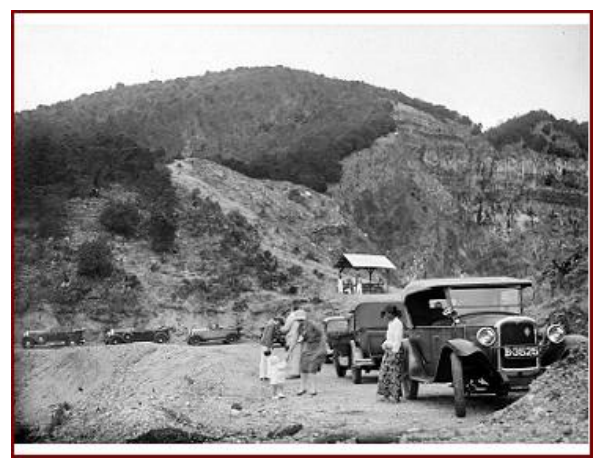

Gambar 3. Kunjungan keluarga R.A. Bergman ke Tangkuban Perahu dengan menggunakan mobil Sumber: KIT

Perjalanan ke kawah ataupun air terjun yang berada di sekitar Priangan merupakan suatu tantangan dan pengalaman yang mengasyikkan bagi para turis, di samping mahalnya biaya 
perjalanan yang harus dikeluarkan. Dalam salah satu panduan yang dikeluarkan oleh Official Tourist Bureau terdapat rangkaian perjalanan yang harus ditempuh oleh para turis bila ingin mengunjungi kawah Gunung Tangkuban Perahu.

Perjalanan menuju Tangkuban Perahu dari Bandung pada tahun 1913 ditempuh dengan menggunakan kereta kuda atau mobil terlebih dahulu hingga ke Lembang. Tarif yang dikenakan untuk perjalanan pulang pergi BandungLembang dengan menggunakan kereta kuda sekitar $f 5,00$ plus uang tip sebesar $f$ 0,5 . Sementara bila menggunakan mobil sebesar $f$ 20,00 dan biaya tambahan sebesar $f 5,00$ untuk per jam bila mobil harus menunggu selama para pelancong mengunjungi kawah. Dari Lembang perjalanan ditempuh dengan menggunakan kuda dengan biaya sebesar $f 3,50$ ditambah biaya kusir atau kuli sebesar $f$ 0,25 per orang (Tourist, 1913: 49).

Selain Kawah Gunung Tangkuban Perahu, Kawah Gunung Papandayan juga menjadi titik menarik kunjungan para pelancong pada masa itu. Gunung Papandayan yang terletak di Kabupaten Garut ini merupakan salah satu destinasi utama para pelancong yang mengunjungi Keresidenan Priangan. Sepanjang perjalanan para pelancong disuguhkan dengan udara tropis yang hangat dan sejuk, serta pemandangan alam yang indah seperti hamparan perkebunan kopi dan kina, riuh suara pepohonan yang berasal dari hutan-hutan sekitar yang ditumbuhi oleh pohon pinus dan akasia, kicauan burung dan suara hewan-hewan sekitar Gunung Papandayan (Tourist, 1913: 54).

Setiba di sekitar kawah, para pelancong biasanya akan sarapan, hal ini karena perjalanan dari Garut ke Papandayan ditempuh hingga dini hari, agar para turis dapat melihat matahari terbit. Setelah sarapan sebentar para pelancong menelusuri keindahan kawah Gunung Papandayan pada pagi hari. Mereka begitu terpesona oleh pemandangan sekitar kawah, kolam lumpur panas, kolam belerang air panas, asap putih yang keluar dari kawah, serta pemandangan hijau lembah Garut dari Puncak Gunung Papandayan. Pemandangan yang mungkin tidak pernah mereka temui baik di Eropa maupun Amerika. Perjalanan ke Gunung Papandayan pada tahun 1913 merupakan perjalanan yang mengasyikkan, namun sedikit melelahkan bagi para pelancong. Mereka harus berangkat dini hari dari Garut, kemudian sarapan di dalam perjalanan dan singgah di sekitar perkampungan. Meskipun melelahkan perjalanan ini sepadan dengan pesona eksotisme yang disuguhkan oleh alam tropis Priangan kepada para pelancong ini (Tourist, 1913: 54-55).

Pengalaman menjelajahi gununggunung di wilayah Keresidenan Priangan, salah satunya dikisahkan oleh H.M. Tomlinson. Perjalanan ke Garut ditempuh oleh Tomlinson dengan menggunakan kereta api dari Batavia. Gambaran mengenai Garut ia lukiskan dengan katakata berikut ini:

"Tempat ini terpencil dalam puncak gunung yang gelap tetapi ladangnya cerah dengan aroma tanah yang segar dan hangat. Dari rerumpunan bambu yang menyusuri birai tertinggi lahan terasering yang luas dan ditanami padi (...). dataran ini cukup tersembunyi untuk menjadi latar upacara drama kehidupan sebuah ras yang hebat"(Tomlinson, 1924 dalam Rush, 2013: 181).

Pada dini hari ia diajak oleh seorang bumiputera untuk mengikuti sebuah perjalanan mengunjungi Gunung Cikuray. Di pagi hari yang dingin ia memulai perjalanan dengan menggunakan kuda. Dipayungi oleh cahaya merah mentari ia menyusuri jalan mendaki ke arah gunung yang cukup terjal. Dalam perjalanan ia melewati sebuah desa kecil dengan kehidupan penduduk yang lestari. Di desa ini ia menikmati sarapan dan meminum kopi sebelum melanjutkan perjalanan dengan jalan kaki. Sepanjang perjalanan ke puncak gunung ia melalui padang rumput 
yang luas, semak berduri, hutan pakis, dan hamparan bunga edelweiss. Setelah tiba di puncak ia melihat pemandangan yang begitu indah, meskipun menurutnya ia tidak nyaman dengan bau sulfur yang ada di sana. Setelah berada di puncak ia benarbenar mengagumi alam Pulau Jawa yang begitu subur dan indah yang bukan hanya khayalan dalam iklan yang menghiasi poster perjalanan seperti yang ia temukan di Singapura, bahkan ia menyebut Pulau Jawa sebagai sebuah Taman Surga (Tomlinson, 1924 dalam Rush, 2013: 182183).

Semakin tingginya minat kunjungan ke lokasi wisata alam di Bandung mendorong "Bandoeng Vooruit" untuk membangun fasilitas yang mempermudah para turis untuk mengunjungi objek-objek wisata ini. ${ }^{13}$ Pada tahun 1928 hingga 1932 "Bandoeng Vooruit" membangun fasilitas jalan langsung ke Gunung Tangkuban Perahu beserta fasiltas-fasilitas penunjangnya seperti hotel dan tempat peristirahatan. Pembangunan jalan ke Gunung Tangkuban perahu ini memiliki arti penting karena mempermudah akses perjalanan wisata ke Gunung Tangkuban Perahu, serta lokasi-lokasi lain terutama yang berada di sekitar Tangkuban Perahu seperti wilayah Lembang dan Dago yang

13 Bandoeng Vooruit adalah sebuah perkumpulan yang terdiri atas arsitek, pengusaha, birokrat, dan elit kolonial di Bandung yang berdiri pada tahun 1925. Mereka memiliki tujuan untuk merencanakan, merancang, dan membangun suatu hunian kolonial yang nyaman di daerah sekitar Bandung. Dalam perkembangannya "Bandung Vooruit" juga melebarkan pengaruh mereka dalam pengembangan pariwisata di wilayah Bandung dan sekitarnya, di antaranya mereka mengelola tempat wisata, hotel, dan fasilitas penunjang wisata di Keresidenan Priangan. Mereka juga memiliki majalah bulanan "Mooi Bandoeng" yang berisi berbagai artikel mengenai dinamika Kota Bandung dan artikelartikel mengenai objek wisata di sekitar Bandung dan Keresidenan Priangan (Mooi Bandung, Februari 1940: 55-62; Kunto, 2014: 265; Colombijn, 2014: 9, 93) juga memiliki pesona alam yang begitu indah. Melalui pembangunan jalan dan fasilitas penginapan di sekitar Tangkuban Perahu, maka pemerintah Gemeente Bandung memberikan konsesi kepada "Bandoeng Vooruit" sebagai pengelola tempat wisata ini (Mooi Bandung, Februari 1940: 57-58).

Selain membangun dan mengelola sarana pariwisata di wilayah sekitar Gunung Tangkuban Perahu, "Bandoeng Vooruit" juga mengembangkan lokasilokasi wisata lain yang berada di sekitar Keresidenan Priangan. Keberhasilan pembangunan jalan dan sarana perhotelan di objek wisata Gunung Tangkuban Perahu mendorong "Bandoeng Vooruit" untuk turut membangun hal yang sama di Gunung Papandayan. Mereka menyelesaikan pembangunan jalan dan penginapan di Papandayan ini pada tahun 1935. Semakin mudahnya akses transportasi ini pada akhirnya turut meningkatkan kunjungan para pelancong ke wilayah Keresidenan Priangan. Hal ini pun semakin ditambah dengan semakin baiknya sarana komunikasi dan media massa pada masa itu, sehingga semakin meningkatkan kunjungan dan kepuasan para pelancong yang mengunjungi wisata alam di Keresidenan Priangan (Mooi Bandung, Februari 1940: 59).

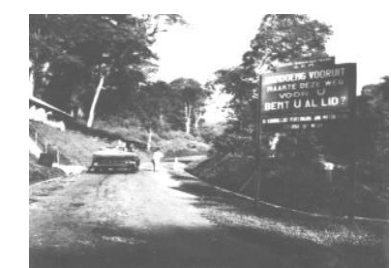

Gambar 4. Fasilitas jalan yang dibangun

"Bandung Vooruit" di Tangkuban Perahu. Sumber: KITLV

Selain menikmati Pegunungan Priangan melalui jalur darat, para pelancong juga dapat menikmati keindahan panorama pegunungan Priangan melalui jalur udara. Pada tahun 1930-an Koninklijk Nederlandsch Indische Luchvaart Maatschapaij (KNILM) atau Maskapai Penerbangan Kerajaan Hindia Belanda membuka jalur penerbangan yang 
dikhususkan untuk pariwisata melintasi Keresidenan Priangan. KNILM membuka jalur penerbangan dari Batavia ke Bandung tiga kali dalam sehari-dua kali ketika musim penghujan (KNILM, 1937: 4-5).

Dalam penerbangan selama lebih kurang 45 menit para penumpang akan disajikan pemandangan alam dari udara di atas dataran tinggi bumi Parahyangan. Dalam rute penerbangan ini para penumpang melewati Gunung Tangkuban Perahu. Penumpang akan disuguhi pemandangan udara kawah dan puncak Tangkuban Perahu serta hamparan hijau dataran tinggi Lembang yang begitu indah, serta hijaunya hamparan perkebunan teh, kopi, dan kina. Dalam mendukung perkembangan pariwisata di Hindia Belanda KNILM memiliki slogan "The Tropics are at your feet" sebagai sarana untuk menarik para pelancong untuk melihat keindahan bumi Hindia dari udara. Selain itu KNILM juga menawarkan tur setengah hari ke Bandung dari Batavia. Tur ini mengajak para pelancong untuk terbang pada pagi hari dari Batavia. Setelah terbang selama lebih kurang 45 menit, para pelancong akan diantar mobil untuk menikmati keindahan alam di Dago dan Lembang, kemudian pada siang hari mereka akan kembali lagi ke Batavia (KNILM, 1937: 6, 7, 27).

\section{Kebun Binatang Bandung: Taman Tropis di Tengah Kota}

Selain wisata alam, pesona flora dan fauna tropis juga menjadi daya tarik para pelancong untuk sekadar melihat atau mempelajari lebih lanjut keanekaragaman flora dan fauna yang ada di alam tropis Hindia Belanda. Pada tahun 1933 di Bandung didirikan kebun binatang dengan menggunakan konsep mini botanical garden. Kebun binatang yang terletak di kawasan Taman Sari, Bandung ini merupakan penggabungan dari dua kebun binatang yang sebelumnya berada di daerah Cimindi dan Dago. Kebun Binatang Bandung ini dikelola secara langsung oleh "Bandung Vooruit". Pendanaan awal pembangunan kebun binatang ini dibiayai oleh Dr. Edward Jacobson dan Dr. W. van den Akker. Sementara kebun binatang ini dirancang oleh Dr. W. Treffers yang sekaligus menjadi direktur pertama kebun binatang ini (Mooi Bandoeng, November 1937: 3).

Menurut Nigel Rothfels dasar dari pembangunan kebun binatang pertama kali yang dimulai di London (1824), Amsterdam (1843), Berlin (1844) dan New York (1862) adalah menghadirkan kehidupan alam liar di tengah kota. Para pemilik dan perancang kebun binatang di Eropa dan Amerika menggunakan istilah "zoological garden", serta membuat suasana kebun binatang sesuai dengan lingkungan aslinya. Sehingga para wisatawan, peneliti, dan konservator tidak perlu jauh-jauh ke tempat asal dari hewanhewan tersebut hanya untuk sekadar mengagumi atau lebih jauh untuk penelitian dan konservasi (Rothfels, 2002:19).

Kebun Binatang Bandung pada masa kolonial merupakan salah satu kebun binatang yang memiliki koleksi cukup lengkap pada masanya. Beragam jenis satwa dari bagian barat dan timur Hindia Belanda dapat ditemui di sini. selain terdapat beberapa satwa yang didatangkan dari luar negeri seperti kangguru, singa, ilama, simpanse, burung flamingo, dan lainnya. Sementara satwa-satwa yang berasal dari Hindia antara lain harimau sunda (Soenda tijger, sic.), orang utan, landak, dan aneka jenis reptil serta burung. Beberapa hewan yang menjadi primadona di kebun binatang ini adalah orang utan kalimantan yang bernama Ramon dan Greta. Berdasarkan cerita dalam majalah Mooi Bandoeng kedua orang utan ini sangat lucu dan pintar. Di kebun binatang ini juga terdapat seekor simpanse yang bernama Max. Max didatangkan dari Afrika, ia merupakan seekor simpanse yang masih muda dan gemar bermain. Selain itu juga terdapat beruang madu dan siamang yang menarik terutama bagi anak- 
anak (Mooi Bandoeng, November 1937: 58).

Kebun Binatang Bandung juga merawat Panther Jawa (sic.), harimau Sunda (Soenda tijger, sic.), dan dua ekor singa Afrika yang diberi nama Radja dan Mirza. Berbagai jenis burung yang menarik dengan nyanyian-nyanyiannya yang indah seperti burung cendrawasih, kakaktua, burung hantu, kapodang dan lainnya. Burung-burung ini dirawat dengan baik dalam kandang dengan disediakan makanan berupa buah-buahan dan daging bagi hewan pemangsa. Di kebun binatang ini juga terdapat hewan-hewan lain seperti buaya, badak jawa, rusa banteng jawa, anoa, dan lainnya. Para pengunjung pada akhirnya tidak harus mengelilingi hutan maupun mencari hewan-hewan ini ke habitat aslinya. Di kebun binatang hewan ini dipamerkan dan dirawat sebagai sarana hiburan dan rekreasi alam yang menarik terutama pada periode akhir kolonial (Mooi Bandoeng, November 1937: 6-8).

Kebun binatang selalu menjadi salah satu daya tarik utama para pelancong yang mengunjungi daerah-daerah tropis, termasuk di Hindia Belanda. Keanekaragaman hayati yang ada di dunia tropis seakan dapat ditampilkan dalam suatu galeri yang menampilkan berbagai jenis satwa dan flora dalam suatu tempat. Kebun binatang menurut Ann Blum menjadi suatu museum sejarah alam yang merekam tentang perkembangan evolusi kehidupan. Pada periode tersebut orangorang Eropa dan Amerika begitu tertarik dengan kehidupan hewan yang liar dan eksotis terlebih bila berada di lingkungan aslinya. Kebun binatang bukan saja menjadi sarana hiburan tetapi sebagai sarana edukasi dan pengetahuan (Lays, 2001: 18; Rothfels, 2002: 6-8).

\section{PENUTUP}

Keresidenan Priangan tumbuh seiring dengan perkembangan ekonomi perkebunan dan perkembangan pariwisata terutama pada periode akhir kolonial. Pesona alam Bumi Priangan telah menarik ratusan ribu pelancong untuk datang, singgah, dan menikmati pesona alam di wilayah ini. Seiring dengan perkembangan pemahaman etnografi dan ketertarikan terhadap eksotisme alam dan budaya timur. Mengutip slogan promosi wisata KNILM "The call of the East" (panggilan dari timur), para pelancong seakan diundang untuk menikmati, menjelajahi, dan bertualang Terra Fantastica bumi Hindia Belanda. Keresidenan Priangan menjadi salah satu destinasi utama para turis yang berkunjung ke Hindia Belanda. Hal ini dipengaruhi oleh beberapa faktor. Pertama, pesona keindahan alam tropis Bumi Priangan yang bukan hanya mempesona, namun juga menghadirkan kenyamanan. Meskipun terletak di daerah khatulistiwa yang panas, namun udaranya begitu sejuk dan nyaman. Maka tidak heran julukan "Europa in de Troupen" dilekatkan pada wilayah ini. Keanekaragaman flora dan fauna yang terdapat di wilayah ini, eksotisme dan keindahan flora dan fauna tropis juga menghadirkan pesona bagi para pelancong yang umumnya berasal dari belahan bumi utara

Faktor kedua adalah fasilitas dan sarana prasarana pendukung ke wilayah ini telah sangat baik. Selain telah adanya Jalan Raya Pos dan jalur kereta api, perjalanan menuju Keresidenan Priangan juga didukung oleh penerbangan teratur oleh KNILM. Dukungan dari organisasi "Bandung Vooruit" juga menjadi faktor utama mengapa Priangan mampu menjadi primadona pariwisata di Hindia Belanda. Pengelolaan berbagai tempat wisata mulai dari Kebun Binatang Bandung hingga Gunung Papandayan memberikan kemudahan para pelancong untuk menikmati keindahan panorama alam di Keresidenan Priangan.

Faktor ketiga adalah kehidupan sosial dan budaya masyarakat Eropa dan Bumiputera yang bersinergi dan harmonis dengan keindahan alam sekitar Bumi 
Priangan seakan memberikan rasa cemburu bagi para pengunjung yang datang ke wilayah ini. Para pelancong dari Eropa, Australia, Singapura, dan Amerika ingin memiliki kehidupan seperti layaknya pemilik perkebunan Priangan (Preangerplanters) yang hidup mewah di tengah hamparan luas perkebunan mereka sambil menikmati udara yang sejuk dan pemandangan alam yang indah, menikmati kegiatan perburuan, mengikuti balap kuda, dan memelihara berbagai hewan tropis yang eksotis. Faktor inilah yang kemudian menjadi pendorong utama dibangunnya penginapan-penginapan di dataran tinggi Priangan seperti di Garut, Leles, Sukabumi, Lembang, dan Sindanglaya.

Faktor keempat yakni banyaknya gunung berapi di wilayah ini. Memasuki abad ke-20 para pelancong juga berhasrat untuk menikmati keindahan gunung berapi. Wisata ke kawah menjadi alternatif yang menarik bagi para turis. Melihat Priangan dari puncak ketinggian terlihat letupan-letupan kolam air dan lumpur panas, serta hasrat penjelajahan dan petualangan menjadi faktor pendorong para turis mengunjungi gunung berapi.

Keempat hal inilah yang dianggap menjadi faktor utama mengapa Keresidenan Priangan mampu menjadi primadona wisata alam di Hindia Belanda. Wisata alam bukan hanya tumbuh karena adanya objek wisata yang indah dan mempesona namun juga harus didukung oleh kelengkapan sarana dan prasarana, serta dukungan dari segenap pihak yang terkait dengan pariwisata di suatu wilayah. Karesidenan Priangan pada periode akhir kolonial menjadi contoh bagaimana ketika pada periode yang masih terbatas sarana dan prasarana pada masa itu, namun mampu menarik kunjungan para turis untuk mengunjungi Bumi Parahyangan.

\section{DAFTAR SUMBER}

\section{Artikel Jurnal}

Demeulenaere-Douyère, Christiane. 2012.
"World Exhibitions: A Gateway To Non-

European Cultures?". Quaderns

d'Història de l'Enginyeria, Vol XIII,

2012 (81-96).

Sunjayadi, Achmad. 2008.

"Mengabadikan Estetika: Fotografi dalam

Promosi Pariwisata Kolonial di Hindia

Belanda". Wacana, Vol. 10 No. 2,

Oktober 2008 (301-316).

\section{Buku}

Barker, Chris. 2014,

Kamus Kajian Budaya. Yogyakarta:

Penerbit Kanisius.

Barnouw, A.J. tt.

A Trip Through The Dutch East Indies.

Gonda: Knuch and Knuttel.

Bloembergen, Marijke. 2006.

Colonial Spectacle: The The Netherlands and The Dutch East Inndies at The World

Exhibition 1883-1931. Singapore: NUS

Press.

Braudel, Fernand. 1979.

Civilisation and Capitalism: The

Structure of Everyday Life, Vol.1.

London: William Collins Sons.

Colombijn, Freek Joan Cote (ed..). 2014. Cars, Conduist, and Kampungs: The

Modernization of the Indonesian City

1920-1960. Leiden: Brill Publication.

Java Motor Club. 1918.

See Java Garden of The East.

Soerabaja: Michael Java Motor Touring

Co.

KNILM. 1937.

Touring Tropics at Top Speed.Batavia: De Unie.

Kunto, Haryoto. 2014.

Wajah Bandoeng Tempo Doeloe.

Bandung: Granasia.

Lays, Stepan Nancy. 2001.

Picturing Tropical Nature, London:

Reaktion Book. 
Official Tourist Bureau. 1910.

Java The Wonderland. Batavia: Official Tourist Beareau.

\section{3.}

Tourist Guide to Buitenzorg, The Preanger, and Kolonial Java. Batavia: Official Tourist Beareau.

Picard, Michel. 2006.

Bali: Pariwisata Budaya dan Budaya Pariwisata. Jakarta: Kepustakaan Populer Gramedia.

Reitsma, S.A. 1930.

"De Spoor en Tramwegen in Nederlansche Indie" dalam Holland Colonial Call, 1930, Holland Colonial Call. The Hague: Dutch-British Publishing Companny, ltd.

Rothfels, Nikel. 2002.

Savages and Beast: The Birth of Modern Zoo. Baltimore: John Hopkins University Press.

Rush, James R. 2013.

Jawa Tempo Dulu: 650 Tahun Bertemu Dunia Barat 1330-1985. Depok:

Komunitas Bambu.

Scidmore, Elizah R. 1897.

Java: The Garden of East. New York:

The Century Co.

Stevenson, Deborah. 2003.

Cities and Urban Cultures. Maidenhead: Open University Press.

Sunjayadi, Achmad. 2007.

Vereeniging Toeristen Verkeer Batavia 1908-1942: Awal Turisme di Hiindia Belanda. Jakarta: FIB UI.

Wearing, Stephen (ed.). 2010.

Tourist Culture: Identity, Place, and The Traveler. London: Sage Publishing.

Weir, David. 2011.

American Orient: Imagining the East From Colonial Era through The

Twentieth Century. Boston: University of Massachussets Press.

de Wit, Augusta. 1905.
Java Fact and Fancies. London: Chapman and Hall Ltd, 1905.

\section{Majalah}

Mooi Bandoeng, November 1937

Mooi Bandoeng, Maret 1939

Mooi Bandoeng, April 1939

Mooi Bandoeng, Februari 1940

\section{Internet}

cnnindonesia.com collectie.wereldculturen.nl Indonesia.travel Media.KITLV.nl 